\title{
PETROGRAPHY AND GEOCHEMISTRY OF THE VOLCANIC ROCKS OF THE RODEIO VELHO MEMBER, ORDOVICIAN OF THE CAMAQUÃ BASIN (RS-BRAZIL): PRELIMINARY RESULTS.
}

\author{
DELIA DEL PILAR M. DE ALMEIDA ${ }^{1}$, RICARDO DA C. LOPES ${ }^{2}$, LARISSA DE LIMA ${ }^{3} \&$ CRISTIANE H. GOMES ${ }^{4}$
}

\begin{abstract}
A geochemical study based in REE, minor elements and petrographic analyses from the volcanic rocks pertaining to the Rodeio Velho Member, comprising lava flows and epizonal intrusive bodies, both corresponding to andesites, subalkaline and alkaline basalts and trachyandesites; and stratified pyroclastic deposits, showed that fractional crystallization of deep source magma is the fundamental mechanism controlling the relationships among these rocks. This igneous event occurred in an alkaline intraplate environment, associated to a widespread extension tectonics, probably corresponding to a final stage of the Pan African - Brasiliano Orogeny during the Middle Ordovician.
\end{abstract}

\begin{abstract}
INTRODUCTION
Outcrop description, petrographic and geochemical analyses of volcanic rocks of the Rodeio Velho Member collected in three different areas located south of the city of Caçapava do Sul, Rio Grande do Sul State, southern Brazil (Fig. 1), allowed to a significative increase in knowledge of this Ordovician magmatic event of the Camaquã Basin.
\end{abstract}

GEOLOGIC SETTING The Camaquã Basin (sensu Paim et al 1995) located at the southernmost region of Brazil, has been connected to a system of late to post-tectonic basins of the Brasiliano Orogeny. During the late stages of this orogenic phase (700 - $500 \mathrm{My}$.), depressions were formed in which sediments resulting from erosion of mountain areas which are still undergoing active uplifting were deposited (Almeida 1969).

Rodeio Velho Member (sensu Ribeiro et al. 1966) was described as an event of a minimum of three flows of vesicular andesites, with estimated thickness of $100 \mathrm{~m}$, without evidences of explosive activity and they display undulary surfaces. These rocks constitute the Guaritas Allogroup of Paim et al. (1995), together with sedimentary alloformations Pedra Pintada (lower) and Varzinha (upper), representing the final stages in the evolution of the Camaquã Basin. The Rodeio Velho magmatism is associated with the lower unit as lava flows, pyroclastic deposits and shallow intrusions, as well as dykes hosted in earlier rocks of the basin.

There are sparse petrographic and geochemical papers about the Rodeio Velho Member. Almeida et al. (1993) suggested a fissural event possibly related to a local hot spot in an extensional intraplate environment. Hartmann et al. (1998) determined a U/Pb age of 470 My. for this event. Silva Filho (1996) showed the intrusive character of this magmatism, despite former ideas of an exclusively volcanic event. Lopes et al. (1999) reported a $119.5-\mathrm{m}$ thick manifestation (CQP-1-RS drillhole north of Camaquã Copper Mines), and suggested that this magmatic event is "related to a new sedimentation cycle, precursor of the Paraná Basin".

Fragoso Cesar et al. (1999) denominated these rocks the Rodeio Velho Intrusive Suite, represented by tabular intrusions in the subhorizontal continental deposits of the Guaritas Group. Almeida et al. (1999) mentioned that this event is a basalt andesitic type of alkaline trend, outcropping as lava flows, pyroclastic deposits and intrusive rocks.

FIELD RELATIONSHIPS In outcrop, lava flows show pahoehoe structures and intrusive bodies are predominantly linear dykes, although some of them occur as sills. Pyroclastic deposits are ash tuffs and/or stratified lapillites. These rocks are amygdaloidal and vesicular.

Region 1 NORTHERN SECTOR at this zone, the Rodeio Velho Member outcrops as four volcanic cones, aligned NNE-SSW, parallel to the regional faults, a clear evidence of a structural-tectonic control in the its emplacement. These cones were preserved due to a later

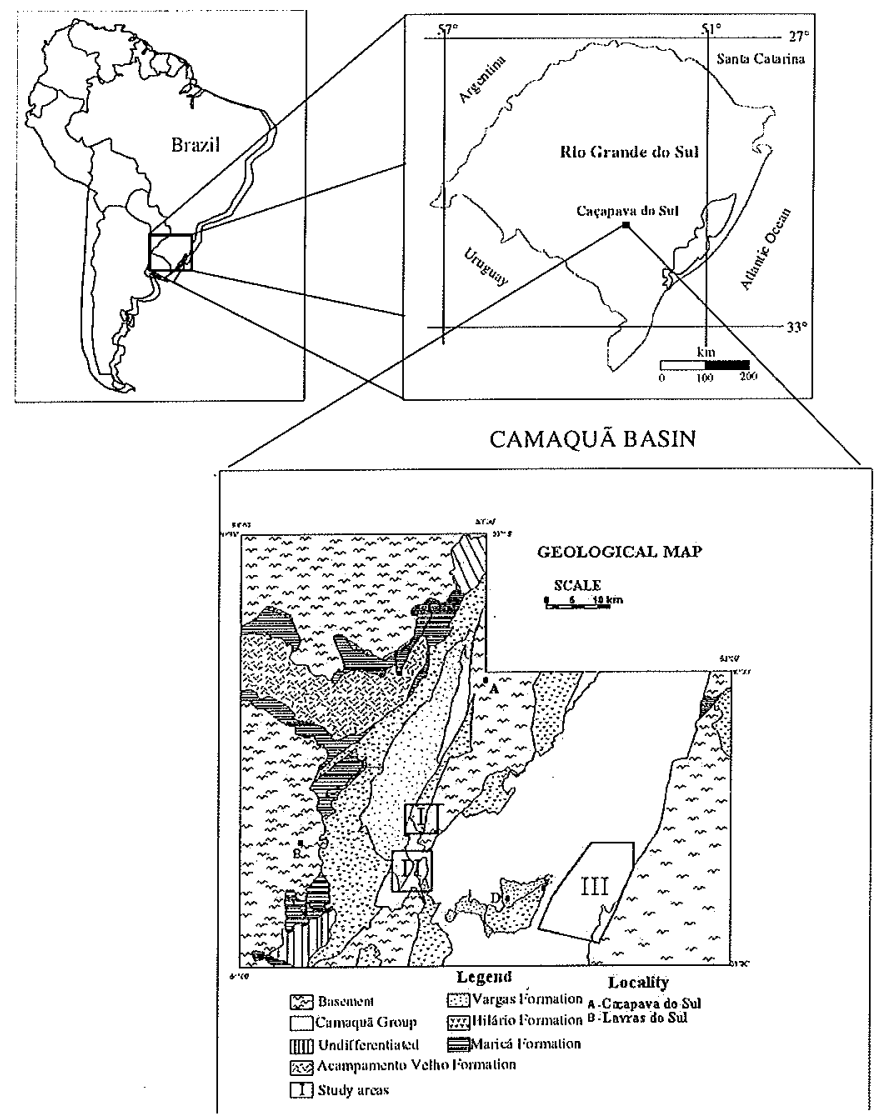

Figure I-Geological and localization map.

deposition of sedimentary rocks corresponding to the upper Ordovician sedimentation of the Varzinha Alloformation. Immediately to the west, there are some dykes hosted in the Santa Bárbara Formation. Those dykes are subvertical, preferentially aligned to $26^{\circ}$, with vesicular and vitreous margins and massive central portions. Ejected blocks of vesicular andesitic/basaltic rocks can be found elsewhere in the area, in addition to localized concentrations of jasper chalcedony and geodes, possibly related to a Strombolian-type event (Hansen et al. 1997).

SOUTHERN SECTOR Two $\mathrm{km}$ south of the cones, at the Arroio Carajá region, the Rodeio Velho Member outcrops as lava flows and intrusive rocks. Flows show $a a$ and pahoehoe structures (Fig. 2) with

1 Mestrado em Geologia, UNISINOS, Av. Unisinos, 950 - CEP. 93022-000 - São Leopoldo/RS. E-mail: Pilar@euler.unisinos.br

2 CPRM/UNISINOS, ricardol.voy@zaz.com.br

3 larissa.lima@zipmail.com.br

4 Graduação em Geologia/UNISINOS - Bolsista PIBIC/CNPq - cris@euler.unisinos.br. 


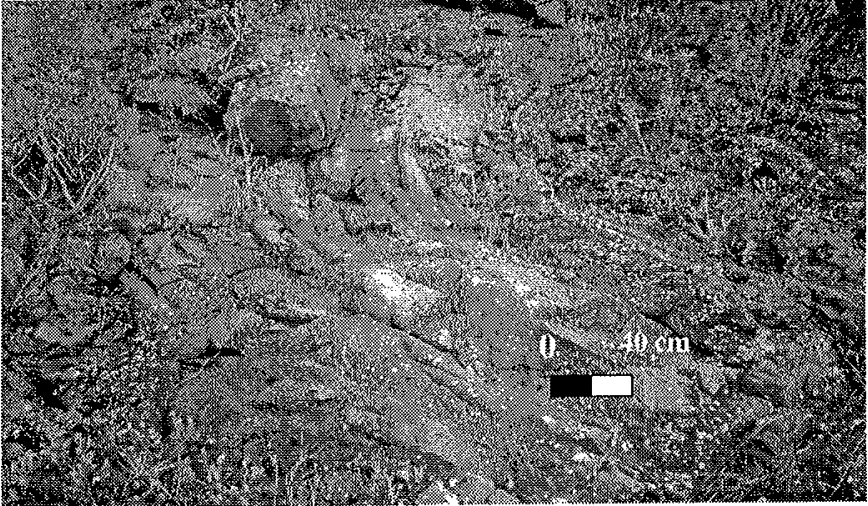

Figure 2 - Detail of rod-like lava flow in the Arroio Caraja region.

centimetric to decimetric hollow tubes, as well as amygdales and/or vesicles up to $5 \mathrm{~mm}$ long, both at the base and top of each flow. Lima et al. (1995) interprets these rocks as typical Hawaiian tholeiitic lava flows, pahoehoe type. These lavas are in normal fault contact with the intrusive facies, which is hosted in rhythmites of the Pedra Pintada Alloformation.

Intrusive contacts with the sedimentary rocks are abrupt or with a reaction border, with assimilation textures. The intrusive body is amygdaloidal, vesicular in places (quartz, celadonite/chlorite, and carbonate). Xenolithes are common along the contact, as slabs of fine sandstone or has "sand dykes", preserving sedimentary structures and ichnofossils. Based on field analyses, emission centers may be situated northwards, possibly related to the cones.

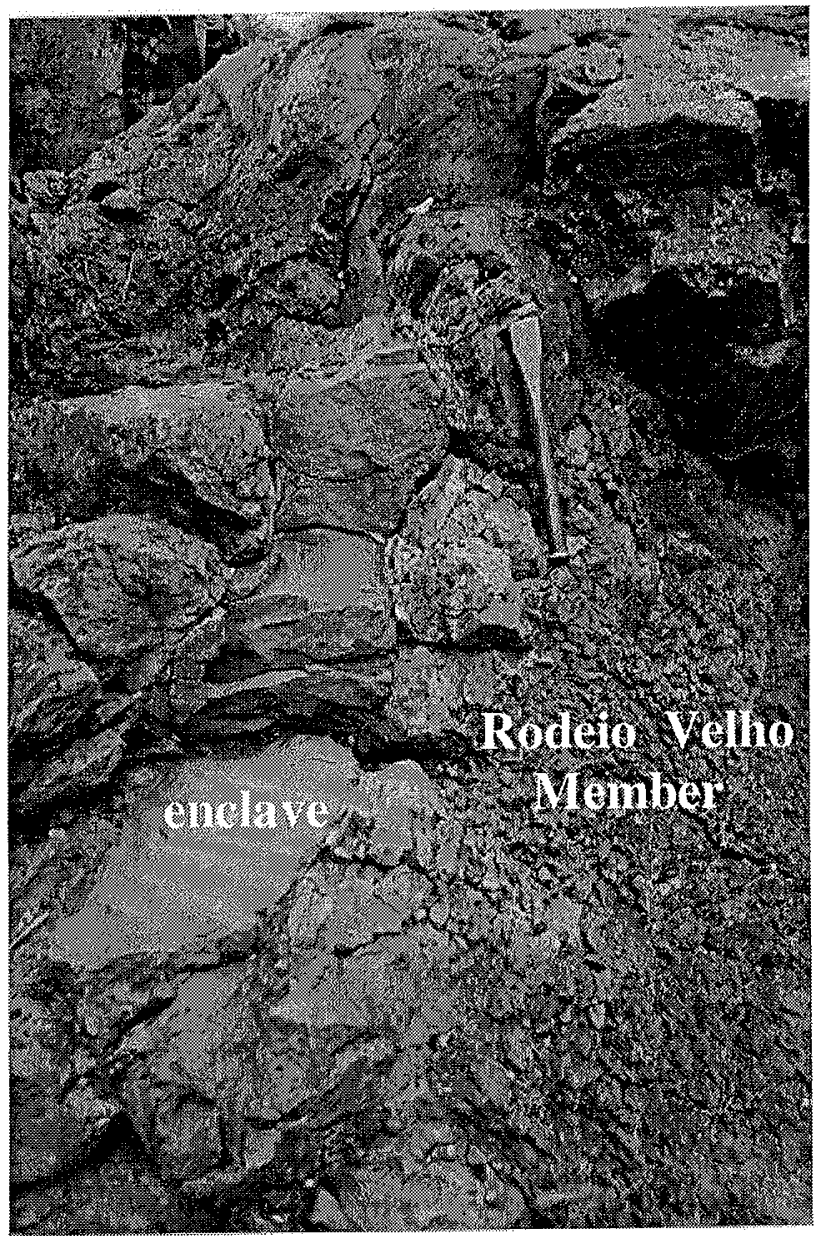

Figure 3 - Detail showing sandstone enclave in amygdaloidal lava in the Passo do Moinho region
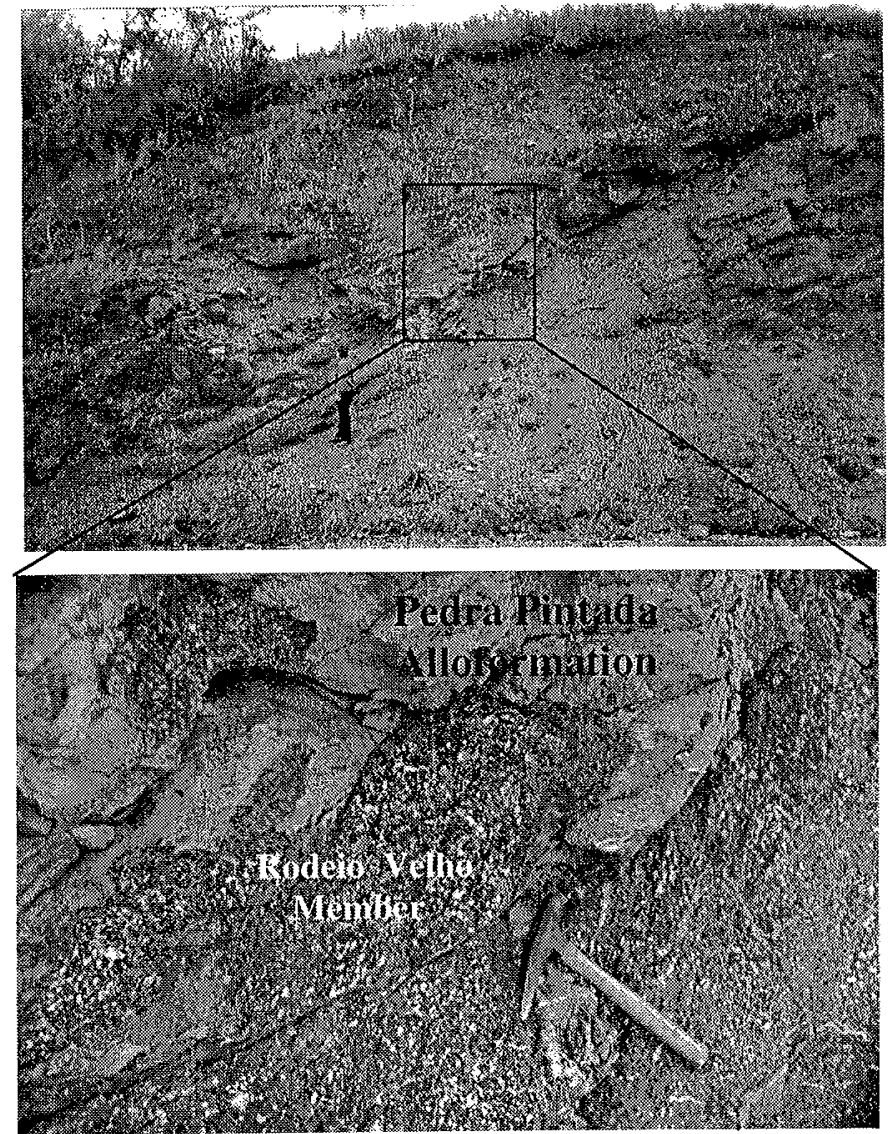

Figure 4 - Intrusive character of the Membro Rodeio Velho in the Pedra da Arara region.

Region 2 At the Rincão da Tigra region, the Rodeio Velho Member exhibits a more complete rock column, from intrusive-facies trough flows and pyroclastics on the top. The intrusive bodies are hosted in metamorphic rocks of the basement and in sedimentary rocks of the Pedra Pintada Alloformation. Pyroclastic deposits occur as stratified and banded ash and lapilli tuffs, with oxidized shards and fiammes. At the bottom, rock clasts characterize this deposit as a breccia. Intrusive facies and lava flows are amygdaloidal and vesicular, massive in places.

Region 3 Intrusive rocks and lava flows occur at the regions of Rodeio Velho, Cerro do Diogo, Pedra da Arara and Arroio dos Neves. Similar to the Region 1, elongated xenoliths of stratified sandstones can be found (Fig. 3), whit preservation of the sedimentary structures.

In the regions of Cerro do Diogo/Pedra da Arara (Fig. 4) to Arroio dos Neves, the Rodeio Velho Member is characterized by its intrusive contact with rhythmites (Pedra Pintada Alloformation), which preserved its sedimentary structures (climbing ripples, load casts and dish and pillar). The intrusion occurs as an amygdaloidal/vesicular dyke filled with carbonate, quartz and celadonite. Vesicles are oriented parallel to the intrusion direction.

PETROGRAPHY Flows and Intrusives (dykes) These rocks have similar textures and mineral compositions. Euhedral to subhedral plagioclase phenocrysts may be partially substituted by carbonate and/or clay minerals. Fractures are filled with oxides. Phenocrysts may or may not be associated to opaque minerals, as isolated grains or in a glomeroporphyritic texture. Accessory minerals are apatite and zircon, together with the opaque minerals. Rock matrix is pilotaxitic, vitrophiric or ophitic, constituted by plagioclase microcrystals and relicts of pyroxenes or olivines, normally associated to minor opaque minerals. Glass is intersectal, recrystallized and forms spherulites or is altered to clay minerals. Amygdales are filled with quartz, carbonate, clay and chlorites. Amygdales/vesicles are present in both intrusive and extrusive facies, showing that magma was rich in a 
volatile phase. Observations on the field showed that intrusive facies and lava flows are very similar, perhaps due to a very shallow intrusion.

Petrographically, lava flows correspond to andesites ( 3 samples), subalkaline basalts ( 2 samples), trachyandesites and alkaline basalts (1 sample each). Intrusive subvolcanic bodies are trachyandesites (2 samples) and alkaline basalts (1 sample).

Tuffs Tuffs are bedded ash tuffs and lapilli tuffs, with a poor selection, composed of shards and fiammes, and brecciated in places, mainly at the base. Clasts composition varies from aphanitic volcanic rock to volcanic rock with plagioclase and euhedral quartz crystals. A dark brown glassy mixture of glass and opaque minerals constitutes the breccia matrix. Microcrystalline quartz occurs in veins or as matrix substitution. The ash tuff is a trachyandesite.

GEOCHEMISTRY The geochemical analyses of major elements, trace elements and rare earth elements (REE) were performed at the Activation Laboratories Ltd., at Ancaster, Canada. Results shown in Table 1 correspond to tuff ( 1 sample), lava flows ( 8 samples, 3 from the volcanic cones) and intrusive rocks ( 3 samples). All rocks show a marked hydrothermal alteration that influences the mobility of the major elements. Thus, the analysis of geochemical data was based mainly on the trace elements and REE, since these more easily controlled by the analyst.

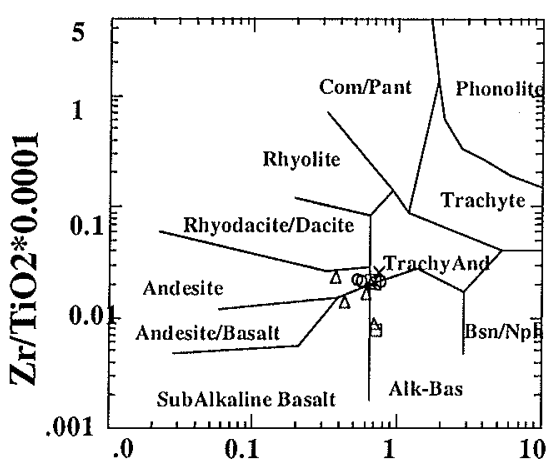

+- tuff

$\Delta$ - flow

- flow (cone)

$0-$ intrusive

Table I-Geochemical analisys of major; trace and REE elements. (1) tuff at Rincão da Tigra; $(2,3,4)$ lava flows (cones) at southeast of Passo do Correio; (5,9) lava flows; $(10,12)$ intrisives. The three types of magmatism produts in the Rodeio Velho are chemically very similar:

\begin{tabular}{|c|c|c|c|c|c|c|c|c|c|c|c|c|}
\hline sample & JKF11 & $\mathrm{PH}-3$ & $\mathrm{PH}-4$ & PH5 & PM49 & PM54 & RLPI & RLP10 & RLP12 & RLP14 & RLP15 & PLR17 \\
\hline & 1 & 2 & 3 & 4 & 5 & 6 & 7 & 8 & 9 & 10 & 11 & 12 \\
\hline $\mathrm{SiO}_{2}$ & 69.71 & 50.14 & 65.53 & 48.55 & 51.47 & 52.93 & 51.89 & 57.12 & 52.33 & 51.69 & 54.63 & 46.84 \\
\hline $\mathrm{TiO}_{2}$ & 0.916 & 2.15 & 1.82 & 1.71 & 2.71 & 2.13 & 1.66 & 2.24 & 1.83 & 1.856 & 1.807 & 2.099 \\
\hline $\mathrm{Al}_{2} \mathrm{O}_{3}$ & 11.12 & 14.64 & 12.7 & 14.14 & 15.69 & 16.2 & 15.75 & 14.58 & 15.77 & 15.79 & 15.34 & 15.77 \\
\hline $\mathrm{Fe}_{2} \mathrm{O}_{3}$ & 7.19 & 11.63 & 6.28 & 9.77 & 13.6 & 13.89 & 8.92 & 10.26 & 8.42 & 10.61 & 11.17 & 12.14 \\
\hline $\mathrm{MnO}$ & 0.05 & 0.16 & 0.1 & 0.17 & 0.16 & 0.1 & 0.26 & 0.13 & 0.09 & 0.07 & 0.08 & 0.09 \\
\hline $\mathrm{MgO}$ & 1.09 & 4.35 & 0.85 & 0.34 & 1.1 & 1.87 & 1.66 & 1.53 & 4.11 & 2.96 & 0 & 3.68 \\
\hline $\mathrm{CaO}$ & 0.41 & 7.4 & 1.99 & 7.64 & 2.45 & 1.04 & 6.57 & 3.3 & 4.97 & 5.18 & 2.68 & 8.26 \\
\hline $\mathrm{Na}_{2} \mathrm{O}$ & 0.81 & 3.45 & 6.01 & 3.34 & 6.36 & 7.57 & 4.59 & 7.6 & 3.89 & 3.78 & 3.9 & 3.7 \\
\hline $\mathrm{K}_{2} \mathrm{O}$ & 5.61 & 1.24 & 1.06 & 6.27 & 1.95 & 0.88 & 2.75 & 0.26 & 2.24 & 2.2 & 5.56 & 1.43 \\
\hline $\mathrm{P}_{2} \mathrm{O}_{5}$ & 0.27 & 1.18 & 1.2 & 0.91 & 1.41 & 0.36 & 1.05 & 1.4 & 1.08 & 1.1 & 1.08 & 0.85 \\
\hline LOI & 2.81 & 3.22 & 1.42 & 5.95 & 2.14 & 2.35 & 4.57 & 1.73 & 3.89 & 3.59 & 2.05 & 4.51 \\
\hline total & 99.98 & 99.56 & 98.94 & 98.78 & 99.05 & 99.32 & 99.68 & 100.15 & 98.62 & 98.83 & 98.83 & 99.37 \\
\hline $\mathrm{K}$ & 46569 & 10293 & 8799 & 52047 & 16187 & 7305 & 22828 & 2158 & 18594 & 18262 & 46154 & 11870 \\
\hline $\mathrm{Ba}$ & 607 & 1780 & 2695 & 2204 & 2093 & 344 & 1124 & 673 & 1150 & 1142 & 1560 & 1140 \\
\hline $\mathrm{Rb}$ & 110 & 15.6 & 13.9 & 94.1 & 28 & 17 & 40 & 4.5 & 29 & 28 & 91 & 26 \\
\hline $\mathrm{Sr}$ & 57 & 1186 & 276 & 222 & 824 & 328 & 558 & 454 & 775 & 808 & 387 & 805 \\
\hline $\mathrm{Tl}$ & 0.6 & 0.2 & 0.2 & 1 & 0.3 & 0.2 & 0.2 & -0.1 & -0.1 & -0.1 & 0.6 & 0.1 \\
\hline $\mathrm{Ta}$ & 0.8 & 1.36 & 1.18 & 1.18 & 2.1 & 0.94 & 1.03 & 1.67 & 1.2 & 1.3 & 1.2 & 1.2 \\
\hline $\mathrm{Nb}$ & 12 & 30.2 & 25.5 & 27.9 & 36 & 19 & 19 & 25 & 27 & 27 & 25 & 20 \\
\hline $\mathrm{Hf}$ & 5.7 & 7.4 & 2.5 & 3.4 & 8.5 & 3.3 & 8 & 7.8 & 8.3 & 7.9 & 7.5 & 3.8 \\
\hline $\mathrm{Zr}$ & 237 & 461 & 399 & 360 & 380 & 185 & 383 & 369 & 395 & 384 & 367 & 164 \\
\hline $\mathrm{Ti}$ & 5491 & 12889 & 10911 & 10251 & 16246 & 12769 & 9952 & 13429 & 10971 & 11127 & 10833 & 12584 \\
\hline $\mathrm{Y}$ & 16 & 54 & 48 & 36 & 84 & 27 & 51 & 41 & 42 & 41 & 36 & 28 \\
\hline Th & 6.8 & 3.47 & 2.61 & 3.41 & 3.7 & 1.4 & 2.9 & 3 & 3.2 & 3.2 & 3.1 & 1.6 \\
\hline $\mathrm{Cr}$ & 94 & 119 & 110 & 87 & 63 & 140 & 84 & 92 & 81 & 83 & 74 & 112 \\
\hline $\mathrm{La}$ & 43.9 & 102.7 & 86.9 & 84.5 & 104 & 40 & 136 & 104 & 76.6 & 77.1 & 80.6 & 42.8 \\
\hline $\mathrm{Ce}$ & 77 & 204.7 & 164 & 168 & 186 & 76 & 217 & 201 & 148 & 145 & 151 & 91.3 \\
\hline $\mathrm{Pr}$ & 9.37 & 20.13 & 16.53 & 16.65 & 23.8 & 11 & 26.6 & 23.8 & 19.5 & 19.6 & 19 & 11.8 \\
\hline $\mathrm{Nd}$ & 30.6 & 91.7 & 75.2 & 72.7 & 95 & 45 & 108 & 97 & 70.4 & 70 & 66.8 & 45.1 \\
\hline $\mathrm{Sm}$ & 5 & 16.2 & 13.7 & 12.2 & 17 & 8.5 & 17 & 16 & 12 & 11.7 & 10.6 & 8 \\
\hline $\mathrm{Eu}$ & 1.4 & 4.81 & 4.02 & 3.52 & 4.81 & 2.52 & 4.45 & 4.46 & 3.58 & 3.43 & 3 & 2.88 \\
\hline $\mathrm{Gd}$ & 4 & 14.5 & 12.8 & 11.2 & 15 & 6.8 & 12 & 11 & 10.1 & 9.7 & 8.7 & 6.8 \\
\hline $\mathrm{Tb}$ & 0.6 & 2 & 1.8 & 1.4 & 2.2 & 1 & 1.7 & 1.6 & 1.5 & 1.4 & 1.3 & 1 \\
\hline Dy & 3.3 & 10 & 8.9 & 6.8 & 12 & 5.5 & 8.9 & 7.6 & 8.1 & 7.7 & 6.8 & 5.8 \\
\hline Ho & 0.6 & 1.9 & 1.8 & 1.3 & 2.4 & 1 & 1.6 & 1.4 & 1.5 & 1.5 & 1.3 & 1.1 \\
\hline $\mathrm{Er}$ & 1.8 & 5.4 & 5.2 & 3.7 & 7.1 & 2.9 & 4.6 & 3.7 & 4.3 & 4 & 3.6 & 3 \\
\hline $\mathrm{Tm}$ & 0.27 & 0.65 & 0.59 & 0.45 & 0.94 & 0.39 & 0.61 & 0.49 & 0.57 & 0.56 & 0.51 & 0.41 \\
\hline $\mathrm{Yb}$ & 1.8 & 4.5 & 3.8 & 3 & 5.5 & 2.4 & 3.5 & 2.9 & 3.5 & 3.4 & 3.1 & 2.5 \\
\hline $\mathrm{Lu}$ & 0.27 & 0.73 & 0.6 & 0.47 & 0.85 & 0.34 & 0.57 & 0.45 & 0.52 & 0.49 & 0.46 & 0.36 \\
\hline
\end{tabular}




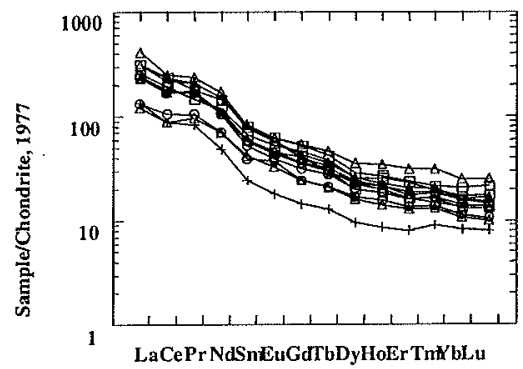

Figure 6 - Chondrite normalized REE diagram (Nakamura 1977).

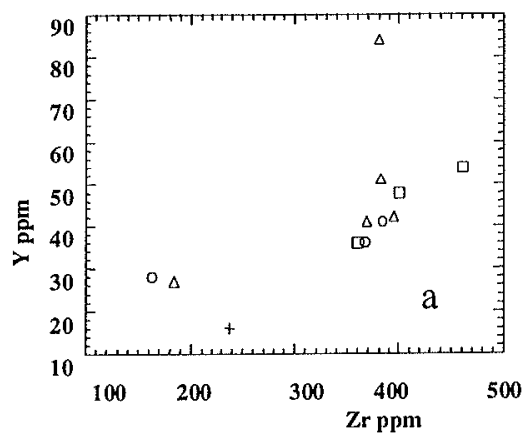

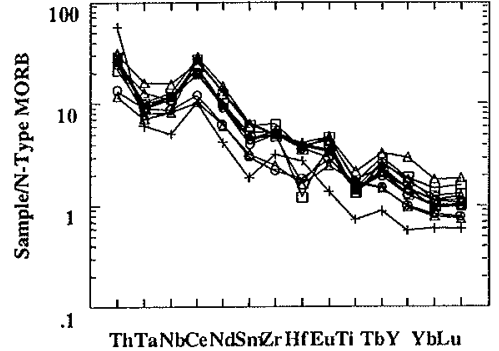

Figure 7-Multi-element spider diagram. Normalizing values are those of Sun \& McDonough (1989) Legend same as in Figure 5.

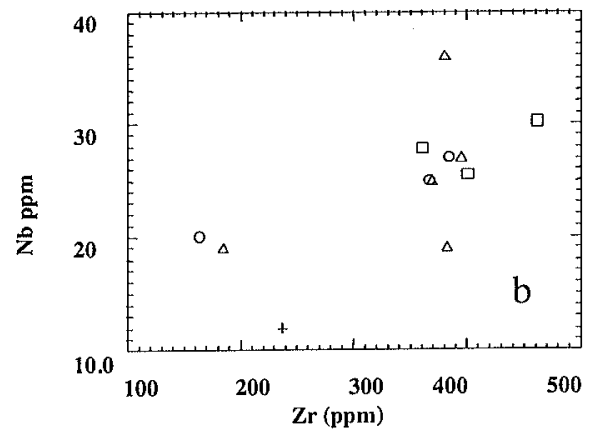

Figure $8 a$ and $8 b-$ Bivariate diagram of $Z r$ versus $Y$ and $N b$. Legend same as in Figure 5
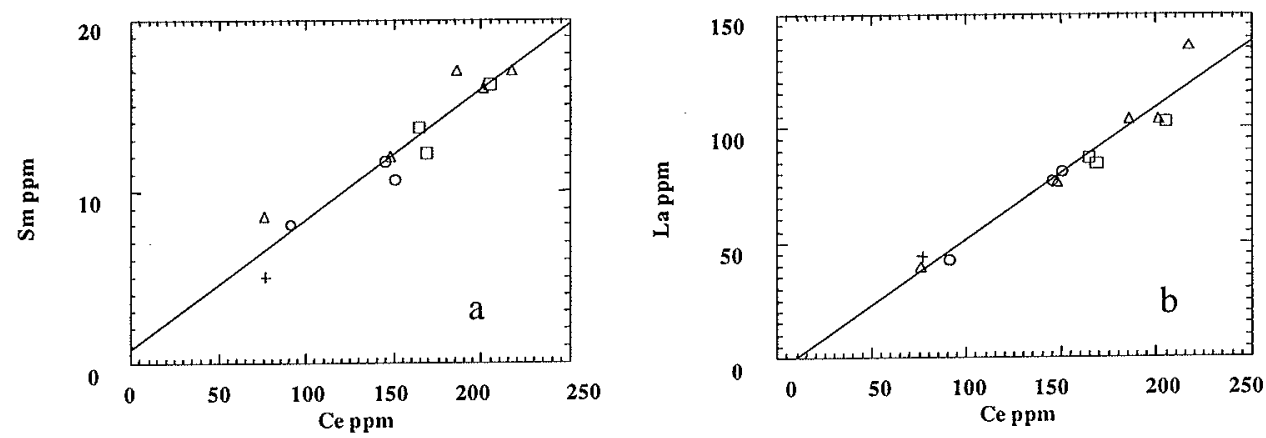

Figure $9 a$ and $b-$ Bivariate diagram of Ce versus $S m$ and La. Legend same as in Figure 5.

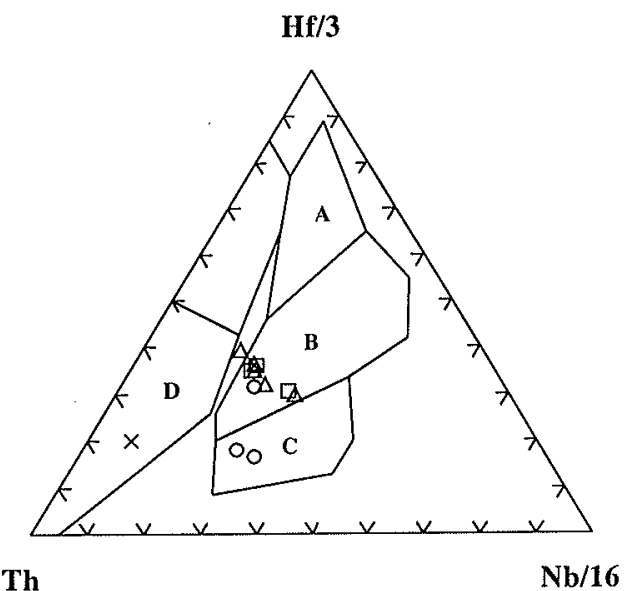

$\Delta$ - flow
- flow (cone)
0 - intrusive
+ - tuff

Th

$\mathrm{Nb} / 16$

Figure 10 - Wood's diagram of tectonic discrimination, 1980. A-N-type MORB; B-E-type MORB and tholeiitic WPB and differentiates; C-Alkaline WPB and differentiates; $D$-destructive plate-margin basalts and differentiates. 


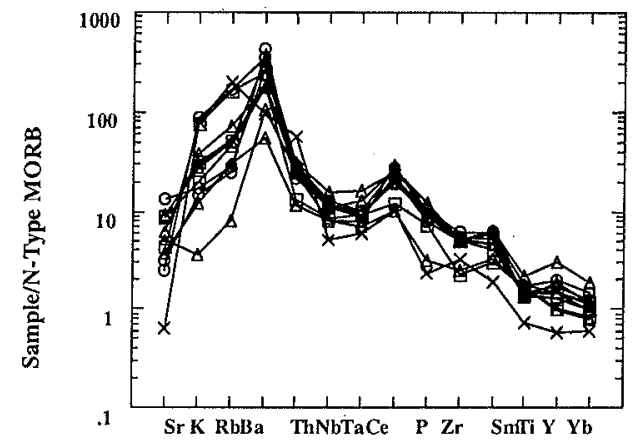

Figure IJ-Multi-element spider diagram normalizing the values of Sun \& McDonough (1989).

From the chemical standpoint, the sequence rocks are represented in diagram $\mathrm{Nb} / \mathrm{Y}$ versus $\mathrm{Zr} / \mathrm{TiO}_{2}$ (Winchester \& Floyd 1977 - Fig. 5), with the flows in the field of subalkaline basalt ( 2 samples), andesite (4 sample), trachyandesite (2 samples) and alkalibasalt (1 sample) and andesite basalts, the pyroclastic in the trachyandesite field and the intrusive in the trachyandesite and alkalibasalt field (1 sample).

The three types of magmatism found in the Rodeio Velho are chemically very similar. Chondrite-normalized REE pattern (Nakamura,1977) show alkaline basalts with no expressive fractioning. The ratio $\mathrm{La} / \mathrm{Yb}_{\mathrm{N}}$ is 16.26 for the tuff, between 11.11 and 25.90 in the flows, and from 11.41 to 17.33 in the intrusives. There is an enrichment of light REE in relation to heavy REE, with a negative Eu anomaly in two samples (flows) and a positive Eu anomaly in one (intrusive) (Fig. 6). Most samples present a negative Ce anomaly, excepting the cones, which shown no anomaly. There is a clear parallel among the spectrum of all analyzed samples, the LREE:HREE ratio being almost constant.

The LREE:HREE ratio is 4.8 for the tuff, between 3.4 and 5.7 in the flows, and an average of 4.1 in the intrusives, confirming the shared magmatic affiliation of the studied rocks. There is a progressive increase in the REE content from tuff to intrusives and flows.

When normalized to N-MORB (Sun and McDonough 1989, Fig. 7), the REE pattern display a clear enrichment of $\mathrm{Nb}, \mathrm{Ce}, \mathrm{Nd}, \mathrm{Sm}$ and $\mathrm{Zr}$ related with $\mathrm{Ti}, \mathrm{Tb}, \mathrm{Y}, \mathrm{Yb}$ and $\mathrm{Lu}$, suggesting an abundance of these elements in the original magma.

Trace elements analyses showed a positive correlation of $\mathrm{Zr}$ with many elements like $\mathrm{Y}$ and $\mathrm{Nb}$ (Fig. 8 a,b), as well as $\mathrm{Al}_{2} \mathrm{O}_{3}$ and REE, despite a gap in the $\mathrm{Zr}$ values of $238 \mathrm{ppm}$ to $359 \mathrm{ppm}$. Other positive correlations exist between $\mathrm{Ce}$ and both Sm and La (Fig. 9a,b). A positive correlation between $\mathrm{Ta}$ and Th characterizes the enrichment of the residual liquid and suggests a fractional crystallization process as mechanism responsible for the evolution of the studied rocks. The negative correlation of $\mathrm{Zr}$ against $\mathrm{Cr}$ and $\mathrm{Ti}$ is understood to be due to the crystallization of mafic minerals and magnetite in the beginning of the process.

GEODYNAMIC ENVIRONMENT The amygdaloidal/vesicular character and hydrotermal alteration of the studied rocks invalidates the use of Irvine and Baragar (1971) classic variation diagrams of $\mathrm{Na}_{2} \mathrm{O}+\mathrm{K}_{2} \mathrm{O}$ versus $\mathrm{MgO}$ versus $\mathrm{FeO}_{1}$ and of $\mathrm{Na}_{2} \mathrm{O}+\mathrm{K}_{2} \mathrm{O}$ versus $\mathrm{SiO}_{2}$. Other trace-elements variations suggest a predominance of intraplate, alkaline or E-MORB basalts, in terms of $\mathrm{Hf} / 3$ versus Th versus $\mathrm{Nb} / 16$, (Fig. 10) (after Wood 1980). This behavior is confirmed in the $\mathrm{Zr} / \mathrm{Y}$ versus - $\mathrm{Zr}$ diagram (Pearce and Cann 1973).

Trace elements were normalized to N-MORB (Sun and McDonough 1989, Fig. 11), in order to more precisely infer the geodynamic environment. A diagram with $\mathrm{LFS}$ ( $\mathrm{Sr}, \mathrm{K}, \mathrm{Rb}, \mathrm{Ba}, \mathrm{Th}$ ) and HFS elements compare basalts in different environments, in which the studied rocks are very similar to intraplate continental basalts (Pearce 1983), with $\mathrm{Sr}$ depletion and slight enrichment in $\mathrm{K}, \mathrm{Rb}$ and $\mathrm{Ba}$. A depletion of $\mathrm{Yb}, \mathrm{Y}$ and $\mathrm{Ti}$ is also visualized.

DISCUSSION The Rodeio Velho Member represents a volcanic/ intrusive sequence affected by an intense weathering or metasomatism, thus, only incompatible trace elements and REE diagrams are considered herein. The AFM diagram shows tholeiitic rocks, although an alkaline character is present in the $\mathrm{Na}_{2} \mathrm{O}+\mathrm{K}_{2} \mathrm{O}$ - versus $-\mathrm{SiO}_{2}$ diagram. The REE pattern is similar to that of alkaline basalts (Figure 6). The alkaline character is confirmed in the REE behavior, with values corresponding to rocks evolved (Culler and Graf 1984) from fractionation and a clear parallelism among all rocks.

Fractional crystallization is the fundamental mechanism controlling the mutual relationships among these rocks. This is confirmed in the identified correlation between incompatible elements, for instance $\mathrm{Ce}$ and $\mathrm{Zr}$. The gap observed may be explained because the studied outcrops are spatially and tectonically distant, in addition to display intense metasomatism/hidrotermal alteration. Thus, this gap may have no geologic meaning and is perhaps overdimensioned by the element mobility.

Based on the REE distribution, an increase of the LREE may occur with low rates of partial fusion and particularly through a garnetdepleted source, which indicates upper-mantle depths for rock generation. Low Sr values may be linked to a primitive magma, at the onset of fractionation. Alternatively, these $\mathrm{Sr}$ data may have no primary magmatic significance due to róck alteration.

The Rodeio Velho Member corresponds to the thermal generator of hydrothermal solutions that generated mineralizations of $\mathrm{Cu}(\mathrm{Ag}, \mathrm{Au})$, $\mathrm{Pb}$ and $\mathrm{Zn}(\mathrm{Cu}, \mathrm{Ag})$ of Minas do Camaquã, Jazida Santa Maria and others (Lima 1998).

The origin of Ce anomalies in volcanic rocks had been widely discussed, but it remains enigmatic. The negative $\mathrm{Ce}$ anomaly shown on this study can be explained by magma contamination by sediments or Ce-depleted rocks.

There is a general agreement that volcanism in the early stages of extension are tholeiticic, for instance during rift generation. So, it is most probable that the studied rocks correspond to a late Pan African - Brasiliano orogenic event. The tectonic process responsible for the Ordovician (470 Ma, Hartmann 1998) volcanism seems to be the reactivation of a localized hot spot, magma ascending trough deepseated faults during distensive tectonism.

CONCLUSION The Rodeio Velho Member corresponds to a late stage of the Pan African - Brasiliano Orogeny, showing intrusive, extrusive and pyroclastic rocks. The intrusive rocks outcrop in fault contact with lava flows and tuffs. The volcanic event manifested in the middle Ordovician, in a continental margin affected by intraplate distensive tectonism. The volcanism corresponds to the locus of thermal generation for the hydrothermal solutions, which in turn are responsible for ore mineralizations in the area.

Acknowledgements To $\mathrm{CNPq}$ for the financial support (process $\mathrm{n}^{\circ} 520896 / 94-7$ ), and to two anonimous reviewers of RBG for the critical review of the manuscript.

\section{References}

Almeida FFM. 1969. Diferenciação Tectônica da Plataforma Brasileira. In: SBG, Cong Bras. Geol., 23, Salvador, Anais, 1:29.46.

Almeida DPM, Paim PSG, Vieira N. 1993. Caracterização Petrográfica e Geoquímica do Vulcanismo Eo-Paleozóico das Bacias de Camaquã e Santa Bárbara (RS). Acta Geológica Leopoldensia, 16(37):145-185.

Almeida DPM, Lopes RC, Lima L, Gomes CH. 1999. Resultados Preliminares do Estudo Petrografico e Geoquimico das Rochas pertencentes ao Mb. Rodeio Velho (Ordoviciano) - Bacia do Camaqua Rs/Brasil In: Simposio sobre Vulcanismo e Ambientes Associados, 1, Gramado, Boletim de Resimos, 15 .

Cullers RL \& Graf JL. 1984: Rare earth elements in igneous rocks of the continental crust: predominantly basic and ultrabasic rocks. In: P. Enderson (ed.) Rare earth Element Geochemistry. Amsterdam, Elsevier, 237-274.
Fragoso Cesar ARS, Fitho WFS, Fambrini GL, Machado R, Riccomini C, Almeida RP, Pelosi APMR, Janikian L. 1999. Significado Tectônico do Magmatismo Rodeio Velho no Rift Guaritas (Eopaleozóico do Rio Grande do Sul, Brasil). In: Simpósio Sobre Vulcanismo e Ambientes Associados, 1, Gramado, Boletim de Resumos, 16.

Hansen MA, Almeida DPE, Fensterseifer HC. 1997. "Morpho-structure of former volcanic Caldera and Cones - Camaquã Basin, Brazil. IAVCEI 97 - Volcanic Activity and environment, Ariais, 14

Hartmann LA, Silva LC, Remus MVD, Leite AD, Philipp RP.1998 Evolução geotectônica do sul do Brasil e Uruguai entre 3,3 Ga e $470 \mathrm{Ma}$. In: Congreso Uruguayo de Geologia, Punta del Este, Uruguay, Actas, 277-284

Irvine TN \& Baragar WRA. 1971. A guide to the chemical classification of the common volcanic rocks. Canadian Journal Earth Science, 8:523-548. 
Lima EF Wildner W, Lopes RC, Sander A, Sommer CA 1995. Vulcanismo neoproterozóico associado às bacias do Camaquã e Santa Bárbara - RS: uma revineoproterozóico associado às bacias do Camaquã e Santa Bárbara- -

Lima L 1998. A Mina Unugua e Jazida Santa Maria - Distrito Mineiro de Camaquã (RS): Um Estudo petrológico, geoquímico e geotermométrico. Unisinos, Sâo Leopoldo. Dissertação de Mestrado, $109 \mathrm{p}$

Lopes RC, Wildner W, Sander A, Camozzato E. 1999. Alogrupo Guaritas: aspectos gerais e considerações sobre o posicionamento do vulcanismo Rodeio Velho (encerramento do Ciclo Brasiliano ou instalação da Bacia do Paraná). In: SBG, Simpósio Sobre Vulcanismo E Ambientes Associados, Gramado, Boletim de Resumos, 17.

Nakamura N. 1977. Determination of REE, Ba, Fe, Mg, Na and $\mathrm{K}$ in carbonaceous and ordinary chodrites. Geoch. Cosmoch. Acta, 38:757-775.

Paim PSG, Chemale Jr. F, Lopes RC. 1995. Aloestratigrafia, Sistemas Deposicionais e Evolução Paleogeográfica da Bacia do Camaquã - Vendiano Superior/Ordoviciano Inferior do RS. In: SBG, Simpósio Sul-Brasileiro de Geologia, São Paulo, Anais 4:39-50.

Pearce JÁ \& Cann JR. 1973. Tectonic setting of basic volcanic rocks determined using trace elements analyses. Earth and Planefary Science Letters, 1:290-300.

Pearce JA. 1983. Role of the sub-continental lithosphere in magma genesis at active continental margins. In: C.J. Hawkesworth and M.J. Norry (Editors), Continental Basalts and Mantle Xenoliths. pp. 230-249.
Ribeiro M, Bocchi PR, Figueiredo F PM, Tessari RI. 1966. Geologia da Quadrícula de Cacapava do Sul, Rio Grande do Sul. Rio de Janeiro, DNPM, 156 p. (Boletim no 127)

Silva Filho WF Fragoso Cesar ARS, Machado R, Sayeg HS, Fambrini GL, Ribeiro de Almeida TI. 1996. O magmatismo Rodeio velho e a Formação Guaritas no

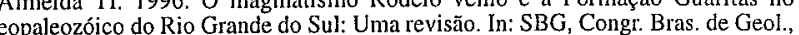
eopaleozóico do Rio Grande do Sul: Una revisão. In: SBG

Sun SS \& Mcdonough WF. 1989. Chemical and isotopic systematics of oceanic basalts: implications for mantle composition and process. In: Magnatism in the ocean basins. implications for mantle composition and process. In: $M$.

Winchester JA \& Floyd PA. 1977. Geochemical discrimination of different magma series and their differentiation products using immobile elements. Chemical Geology, 20:325-343

Wood DA. 1980. The application of a Th-Hf-Ta diagram to problems of tectonomagmatic classification and to estabilishing the nature of crustal contamination of basaltic lavas of the British Tertiary volcanic province. Earth and Planetary Science Letters, 50:11-30.

Manuscrito A-1157

Recebido em 15 de fevereiro de 2000 Revisão dos autores em 30 de março de 2000 Revisão aceita em 20 de abril de 2000 